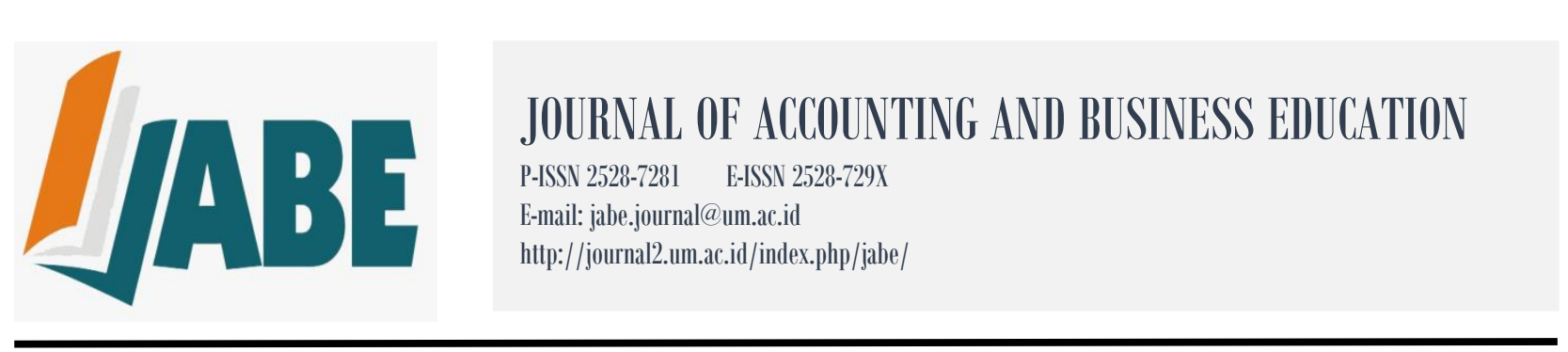

\title{
Analysis on Earnings Persistence, Independent Commissioner and Herding Behavior on Earnings Quality
}

\author{
Ike Arisanti \\ Accounting Department, Faculty of Economic, Universitas Muhammadiyah Malang, Indonesia \\ email: ikearisanti@umm.ac.id
}

DOI: http://dx.doi.org/10.26675/jabe.v3i2.6846

\begin{abstract}
This study aims at determining the effect of independent commissioners, earnings persistence, and herding behavior on earnings quality. This study employs a multiple linear regression analysis with SPSS as the statistical tool.Before conducting the hypothesis test, a classical assumption test is conducted first, determining whether the data have met the classical assumptions and may be applied to the regression model. There are four components used in the classical assumption test, namely normality test, multicollinearity test, heteroscedasticity test, and autocorrelation test. This study takes 80 qualified manufacturing companies listed with the Indonesia Stock Exchange in 2017 as the object with a purposive sampling technique. The earnings quality variable is measured using ERC, the Herding behavior is measured using Cross Sectional Absolute Deviation (CSAD), the Independent Commissioners are measured by comparing the number of independent commissioners with overall commissioners in the companies, and the earnings persistence is measured by comparing current earnings with past earnings. The results of this study partially show that earnings persistence variable, independent commissioners and herding behavior do not influence the quality of earnings.
\end{abstract}

Keywords: earnings persistence; independent commissioner; herding behavior; earnings quality

\section{INTRODUCTION}

Financial statement is one medium of communication which may be used by both corporate internal and external parties to examine a company's condition. Financial statement may be used as the basis of making some decisions, such as assessing management's performance, determining compensation for management's, dividend policy, etc. Earnings are information existing in financial statement. Information of corporate earnings is quite important since it may be used to assess a performance, predict future earnings and predict investment risks or credit risks, Kirschenheiter and Melumad in Marisatushokha and Budiono (2015). The importance of earnings information is expressly stated in the Statement of Financial Accounting Concept (SFAC) No. 2 that earnings information is the main element in financial statement and very important for they who use it since it has a predictive value (FASB, 1980; Boediono, 2005; Marisatusholekha and Budiono, 2015). Earnings a company successfully attains are one measure of performance and taken into account by investors or creditors in investment or providing additional credit decision making (Riyatno, 2007). 
According to the Agency Theory, separation between corporate ownership and management may cause conflict. Such conflict, referred to as agency conflict, is caused by the concerned parties, the principal (one who grants contract or shareholders) and the agent (one who receives contract and manage principal's fund), who have conflicting interests, Rachmawati and Triatmoko in Marisatushokha and Budiono (2015). With such conflict of interest, that there is moral hazardor fraud made by the management to report earnings inappropriate to corporate real condition cannot be denied. This may influence the quality of earnings reported by the company.

Earnings quality is influenced by board of commissioners' supervision of what executives or directors do (Farida, 2012). The role of board of commissioners in creating good corporate governancein company is expected to go up with the existence of independent commissioner to oversee the company, (Rosdini, 2010). Board of independent commissioners is a party unaffiliated to majority shareholder, members of directors and or other members of board of commissioners (Farida, 2010). According to the results of research conducted by Farida (2012), board of independent commissioners positively influences earnings quality. Meanwhile, according to the results of researches conducted by Rupilu (2012), Christiantie \& Christiawan (2013), Rosdini (2010) and Putri and Fitriasari (2017), board of independent commissioners does not influence earnings quality.

Earnings persistence is company's ability to maintain its earnings from year to year. Penman and Zhang (2002) in Fanani (2010) define earnings persistence as revision in accounting expected future earnings caused by current earnings innovation. Earnings persistence reflects corporate earnings quality and shows that a company may maintain its earnings from time to time (Susanto, 2012). The results of research conducted by Mulyani, Asyik, \& Andayani (2007) show that earnings persistence significantly influences earnings response coefficient(ERC), while the research conducted by Putri and Fitriasari (2017) shows that earnings persistence does not influence ERC. The quality of earnings in the financial statements will be very useful for the capital market because it will make investors measure the value of a company as a basis for investing (Jonathan \& Machdar, 2018).

The background of this research is the inconsistency of previous researches' results, in which many previous researches show different research results and objects. Besides, the author is interested in adding herding behavior variable since no research has added herding behavior variable to earnings quality, and thus to study the influence of independent commissioner, earnings persistence and herding behavior on the earnings quality of manufacturing companies registered with the Indonesia Stock Exchange in 2017. The novelty of this research is the addition of herding behavior variable, in which the researcher adds corporate external factors related to investor's behavior in examining how they influence earnings quality. This research takes the manufacturing companies registered with the Indonesia Stock Exchange as objects since they consist of various sectors and represent most of companies in Indonesia. Based on the background above, the purpose of this research is to examine the influence of independent commissioner, earnings persistence, and herding behavior on the earnings quality of manufacturing companies registered with the Indonesia Stock Exchange in 2017. This research presents theoretical benefit of addition to reference and science, particularly in the field of accounting. For practical benefit, this research may serve as reference in decision making related to independent commissioner and earnings persistence.

\section{LITERATURE REVIEW AND HYPOTHESES}

\section{Agency Theory}

The agency theory discusses the relationship between principal and agent, in which principal means shareholders and agent means management. According to Indrawati \& Yulianti (2010), the agency theory's view that there is separation between agent and principal which may result in potential conflict may influence the earnings quality reported. The reason of management and ownership functions separation is that principal has limited capability in managing company which may lead to information asymmetry. According to Priantinah, in Putri and Ftiriasari (2017), agent knows corporate future internal information better than principal. This may cause conflict of interest between both parties. There is a 
possibility that management does not work in representing principal's interest and prioritizes their own interest by maximizing their subjective utilities (Rahmawati, 2005).

\section{Efficient Market Hypothesis}

According to Fama (1970), Efficient Market Hypothesis (EMH) is reasoning that stock price has reflected all available information. EMH consists of three versions classified by definition of the availability of information which may be obtained by investors, which are weak, semistrong, and strong. The efficient market theory states that market will immediately react to new information. Based on the efficient market hypothesis, the price of a security reflects all information related to a company, including its future financial performance and future prospect.

The weak version states that stock price has reflected all existing information in the market as reflected in the prices of current securities and return. This first type efficiency satisfies the random walk hypothesis since price moves randomly without relevance. The semistrong version states that all existing public data related to company's prospect should have been reflected in market price. The concerned data are, for example, stock splits announcement, corporate financial statement, stock issue, etc. Therefore, if all investors can easily obtain this information, they will be directly reflected in market price. The strong version states that all information from investors or group (for example: mutual funds management) with access to information, both public and private, has been reflected in market price (Fama, 1970).

\section{Independent Commissioner and Earnings Quality}

The composition of the independent commissioners in the Securities Exchange Regulations, item 1-a of the Securities Listing Regulation No. 1-A PT Bursa Efek Jakarta (now the Indonesia Stock Exchange) concerning general provisions for the listing of Equity-Type Securities at the Exchange regulates the ratio of independent commissioners. In this item it is stated that the number of independent commissioners must be proportional to the number of shares held by parties who are not controlling shareholders, provided that the number of independent commissioners is at least $30 \%$ (thirty percent) of the total number of commissioners(Nasution, Nazar, \& Aminah, 2018).

Independent commissioner means commissioner other than member of management, majority shareholder, official or otherwise directly or indirectly related to majority shareholder of a company which oversees the company's management (Surya \& Yustiavandana, 2008). Independent commissioner's task is to serve a supervisory function, so that board of commissioners will more objectively exercise its tasks. Through the role of the board in carrying out the supervisory function of the company's operations by the management, the composition of the board of commissioners can make an effective contribution to the results of the quality report preparation process or the possibility of avoiding fraud financial statements (Budianto \& Samrotun, 2018).

Khancel in Khafid (2012) sates that independent commissioner monitors management more effectively, thus independent commissioner will oversee company's management in achieving company's purpose of gaining persistent earnings. Mashayekhi and Bazaz in Nurochman and sholikhah (2015) state that an increasing number of independent commissioners will influence corporate earnings quality in terms of earnings persistence. The research conducted by Febiani (2012) concludes that independent commissioner significantly influences ERC coefficient, in which the possibility of financial statement fraud will decrease with financial statement supervision, thus it limits the extent of corporate earning management. This shows that the existence of independent commissioner in a company may influence corporate earnings quality.

H1 : Independent commissioner influences earnings quality

\section{Earnings Persistence and Earnings Quality}

According to Kormendi and Lipe; Easton and Zmijweski (1989) as quoted by Mulyani, Asyik \& Andayani (2007), earnings persistence is positively related to earnings responsecoefficient. This means that the more permanent the change of earnings from time to time, the higher the earnings coefficient is, 
since this condition shows that corporate earnings keeps increasing. Company which may retain earnings will increase market response. This market response shows that earnings information reported by company has quality.

Published earnings generate various responses, showing the existence of market reaction to earnings information (Cho and Jung, 1991 in Putri and Fitrisari 2017). Market reaction to published earnings will depend on investor's assessment (perception) of the quality of earnings nominal a company generates and publishes. Earnings Response Coefficients(ERC) is believed to give a clear idea of earnings quality by viewing market reaction to the published earnings information. Market reaction reflects the quality of corporate published earnings and the value of Earnings Response Coefficients(ERC) is greatly determined by the responsive power reflected in information contained in earnings (Suaryana, 2005). This means that the stronger the market response to earnings information reflected in the high value of Earnings Response Coefficients (ERC) shows the higher the quality of published earnings and vice versa.

The higher the profit persistence of a company, the higher the response of investors to invest their funds in the company. The higher investor response reflected in the high ERC reflects increasingly quality earnings. The higher the profit persistence, the higher the quality of earnings(Ardianti, 2018)

Fauziah (2017)Persistent profit will have a positive effect on earnings quality. Investors assume that when company has persistent earnings from time to time, they may expect for higher future earnings. This will be well responded by the market, as reflected with high ERC value, indicating quality earnings. Theoretically, therefore, persistent earnings influences corporate earnings quality (Kormendi and Lipe, 1990, in Putri and Fitriasari, 2017)

$\mathrm{H} 2$ : Earnings persistence influences earnings quality

\section{Herding Behavior and Earnings Quality}

According to Muema (2014), herding is investor's behavior in following other investor's action and following other investor's decision. Market makers trade in the same direction and at the same time and form correlated behaviors between one investor to another. Asri (2015) is of the opinion that the herding theory describes situation in which people do together something that many other people do.

In the signaling theory, arising positive signal will stimulate investors' reaction to buy stock. According to Bikhchandani and Sharma (2001), when an investor has limited information, the investor will follow other investor's move in making investment decision. He will eventually leave his signal and follow majority investors' decision (herding behavior). The efficient market theory states that market will react to any new information. Based on efficient market hypothesis, the price of a stock security reflects all information related to company, including current financial performance and its future prospect. Company that discloses positive earnings will be responded as positive information by some investors and such information will be utilized by investors with limited information to do herding behavior. This investor's response shows that earnings information the company reports has the quality.

H3 : Herding Behavior influences earnings quality

\section{METHODS}

This quantitative research employs secondary data derived from www.idx.co.id in the form of 2017 financial statement and from yahoo finance in the form of stock price and IDX composite. In conformance to the disclosed title, there are 3 variables in this research. This research's dependent variable is earnings quality, while its independent variables are independent commissioner, earnings persistence and herding behavior. 


\section{Population, Samples, and Sampling Technique}

The population of this research is manufacturing companies registered with the Indonesia Stock Exchange in 2017. This research employs non-probability purposive sampling based on the criteria presented in table 1 below:

Table 1. Sampling Criteria

\begin{tabular}{ll}
\hline Criteria & Quantity \\
\hline Manufacturing companies registered with the Indonesia Stock Exchange in 2017 & 153 \\
Manufacturing companies with abnormal positive return during observation & 80 \\
period & 0 \\
\hline Unaudited Financial Statement & 0 \\
\hline \multicolumn{1}{c}{ Total samples during research period } & 80 \\
\hline
\end{tabular}

Source: Processed Data, 2018

\section{Variables' Operational Definition}

\section{Independent Commissioner}

Independent Commissioner is, according to Christiantie and Christiawan (2013), measured using the formula:

$\mathrm{KI}=$ Number of members of board of commissioners from external party

All members of company's board of commissioners

\section{Earnings Persistence}

Earnings persistence is measured in regression slope on the difference between current earnings and previous earnings (Mulyani, Asyik \& andayani, 2007) with formula:

$$
\begin{aligned}
& \text { Xit }=\alpha+\beta \mathrm{X}_{\mathrm{it}-1}+\varepsilon_{\mathrm{t}} \\
& \text { Where: } \\
& \alpha=\text { Constant } \\
& \text { Xit = Company i's earnings year } \mathrm{t} \\
& \text { Xit-1 = Company i's earnings year } \mathrm{t}-1 \\
& \beta=\text { Regression coefficient (earnings persistence) } \\
& \varepsilon_{\mathrm{t}}=\text { Error component in model }
\end{aligned}
$$

\section{Herding Behavior}

The CSAD (Cross Sectional Absolute Deviation) method developed by Chang, Cheng, Dan Khorana in 2000 is employed for the herding behavior variable. Below are measures used in detection of herding behavior:

a. Calculate stock daily return from the first day to the $5^{\text {th }}$ day after publication of financial statement.

b. Calculate the $\mathrm{CSAD}_{\mathrm{t}}$ of stock daily return for each of company's stock and calculate the extent of market return. In this research, the $\mathrm{CSAD}_{\mathrm{t}}$ is calculated using the formula below:

$\operatorname{CSAD}_{\mathrm{t}}=\frac{1}{N} \sum_{i=1}^{N}\left|\mathrm{R}_{\mathrm{i}, \mathrm{t}}-\mathrm{R}_{\mathrm{m}, \mathrm{t}}\right|$

Where:

$\mathrm{CSAD}_{\mathrm{t}}$ : Cross Sectional Absolute Deviation

$\mathrm{R}_{\mathrm{i}, \mathrm{t}}$ : return of individual stock in period $\mathrm{t}$

$\mathrm{R}_{\mathrm{m}, \mathrm{t}}$ : market return in period $\mathrm{t}$

$\mathrm{N}$ : number of sample companies

c. Explore the value data of $\mathrm{CSAD}_{\mathrm{t}}$, marketreturn, and stock return using descriptive statistics. Stock return is calculated using the formula below:

Stock Return : $=\left(\mathrm{P}_{\mathrm{t}}-\mathrm{P}_{\mathrm{t}-1}\right) / \mathrm{P}_{\mathrm{t}}$

Where:

Stock Return : Initial Return

$\mathrm{P}_{\mathrm{t}}$ : Stock price on the first day after IPO. 
$\mathrm{P}_{\mathrm{t}-1}$ : Stock price during IPO.

d. Perform regression of the data of $\operatorname{CSAD}_{t}$ with market return at $\alpha=0.05 \%$. The formula below is used:

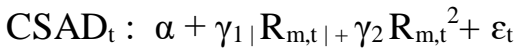

Where:

$\alpha$ : intersect variable

$\gamma_{1}$ : linear coefficient between CSAD and market return portfolio

$\gamma_{2}$ : non-linear coefficient between CSAD and market return portfolio (Herding)

$\mathrm{R}_{\mathrm{m}, \mathrm{t}}$ : market return in period $\mathrm{t}$

$\varepsilon_{\mathrm{t}}:$ standard error

\section{Earnings Quality}

This research employs a market adjusted model. The phases of ERC calculation are, according to Andreas(2012), as follows:

a. Abnormal Return

$\mathrm{AR}_{\mathrm{it}}=\mathrm{R}_{\mathrm{it}}-\mathrm{RM}_{\mathrm{it}}$

Where:

$\mathrm{AR}_{\mathrm{it}}=$ Stock abnormal return $\mathrm{i}$ in period $\mathrm{t}$

$\mathrm{R}_{\mathrm{it}}=$ Stock return i period $\mathrm{t}$

$\mathrm{RM}_{\mathrm{it}}=$ Market return $\mathrm{i}$ in period $\mathrm{t}$

b. Stock Return

$\mathrm{R}_{\mathrm{it}}=\frac{\left(\mathrm{P}_{\mathrm{it}}-\mathrm{P}_{\mathrm{it}-1}\right)}{\mathrm{P}_{\mathrm{it}-1}}$

Where:

$\mathrm{R}_{\mathrm{it}}=$ Stock return $\mathrm{i}$ in period $\mathrm{t}$

$\mathrm{P}_{\mathrm{it}}=$ Stock closing price $\mathrm{i}$ in period $\mathrm{t}$

$\mathrm{P}_{\mathrm{it}-\mathrm{1}}=$ Stock closing price $\mathrm{i}$ in period $\mathrm{t}$

c. Market Return

$\mathrm{RM}_{\mathrm{it}}=\frac{\left(\mathrm{IHSG}_{\mathrm{it}}-\mathrm{IHSG}_{\mathrm{it}-1}\right)}{\mathrm{IHSG}_{\mathrm{it}-1}}$

Where:

$\mathrm{RM}_{\mathrm{it}}=$ Market return $\mathrm{i}$ in period $\mathrm{t}$

$\mathrm{IHSG}_{\mathrm{it}}=\mathrm{IDX}_{\mathrm{T}}$ composite in period $\mathrm{t}$

$\mathrm{IHSG}_{\mathrm{it}-1}=\mathrm{IDX}$ composite period $\mathrm{t}-1$

d. Cumulative abnormal return

$\mathrm{CAR}_{\mathrm{it}}=\sum \mathrm{AR}_{\mathrm{it}}$

Where:

$\mathrm{CAR}_{\text {it }}=$ Cumulative abnormal return of stock of company i several days before and several days after date of annual earnings publication.

$\mathrm{AR}_{\mathrm{it}}=$ Abnormal return of stock i during window period

The calculation of abnormal return and cumulative abnormal return in this research employs window period of eleven days, which is five days after $(t+5)$ publication of financial statement pursuant to research conducted by Delvira \& Nelvrita (2013).

e. Unexpected Earnings

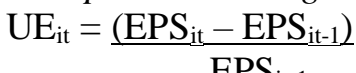

Where:

$\mathrm{UE}_{\mathrm{it}}=$ Unexpected earnings of company $\mathrm{i}$ in period $\mathrm{t}$

$\mathrm{EPS}_{\mathrm{it}}=$ Earnings per share of company $\mathrm{i}$ in period $\mathrm{t}$

$\mathrm{EPS}_{\mathrm{it}-1}=$ Earnings per share of company $\mathrm{i}$ in period $\mathrm{t}-1$ 
f. Earnings Response Coefficient (ERC)

$\mathrm{CAR}=\beta_{0}+\beta_{1} \mathrm{UE}_{\mathrm{it}}+\mathrm{E}$

Where:

CAR = Cumulative abnormal return of stock of company i several days before and several days after date of annual earnings publication.

$\mathrm{UE}_{\mathrm{it}}=$ Unexpected earnings of company $\mathrm{i}$ in period $\mathrm{t}$

$\beta_{0}=$ Constant

$\beta_{1}=$ Earnings Response Coefficient (ERC)

$\mathrm{e}=$ Error term

\section{Hypothetical Test}

This research employs a multiple linear regression model. The multiple linear regression equation in this research is as follows:

KU_LA $=\alpha+\beta_{1} \mathrm{KI}+\beta_{2} \mathrm{PL}+\beta_{3} \mathrm{HDG}+\varepsilon$

Where:

$$
\begin{array}{ll}
\text { KU_LA } & =\text { Earnings Quality } \\
\alpha & =\text { Constant } \\
\beta_{1} \beta_{2} & =\text { Regression Coefficient } \\
\mathrm{KI} & =\text { Independent Commissioner } \\
\mathrm{PL} & =\text { Earnings Persistence } \\
\mathrm{HDG} & =\text { Herding Behavior } \\
\varepsilon & =\text { Error }
\end{array}
$$

\section{RESULTS}

The partial test on the Independent Commissioner variable table results in significance value of 0.722 . The criteria for $\mathrm{t}$ statistical test determine a significance value $0.722>0.05$, thus $\mathrm{H} 1$ is Rejected or, in other words, independent commissioner does not significantly influence earnings quality. This research conforms to the research conducted by Marisatussholekha and Budiono (2013) that investor's response to earnings quality is not determined by the number of independent commissioners in company.

The partial test on the earnings persistence table results in significance value of 0.224 . The criteria for statistical test determine a significance value $0.224>0.05$, thus $\mathrm{H} 2$ is Rejected or, in other words, earnings persistence does not significantly influence earnings quality. The partial test on the herding behavior table results in significance value of 0.339 . The criteria for statistical test determine a significance value $0.339>0.05$, thus $\mathrm{H} 3$ is Rejected or, in other words, herding behavior does not significantly influence earnings quality. The conclusion of the hypothesis testing can be desrcibed below: Table 2. $t$ test or partial test

\begin{tabular}{lll}
\hline Variable & T (Sig) & Conclusion \\
\hline KI & $0.013(0.722)$ & H1 is Rejected \\
PL & $-0.216(0.224)$ & H2 is Rejected \\
HDG & $-0.013(0.339)$ & H3 is Rejected \\
\hline
\end{tabular}

\section{DISCUSSION}

The results of this research conform to the research conducted by Rosdini (2010), that the reason independent commissioner does not influence earnings quality is that company with high proportion of independent commissioners tend to have low ERC value. This is shown with the low ERC value of companies with high number of independent commissioners, which means that investors do not consider the number of independent commissioners as their basis of investment decision. The reason independent 
commissioner variable does not influence earnings quality is likely independent commissioner's minimum contribution to and capability in the effort to drive and create more objective climate and put fairness as the main principle in considering minority shareholders' and other stakeholders' interests.

One measure or proxy for measuring earnings quality can be used earnings response coefficient (ERC). The strong market reaction to earnings information reflected in the ERC value will show that reported earnings are of high quality. Earnings Response Coefficient (hereinafter written with ERC) can be defined as the effect of one currency unit of expected profits on stock returns and describes the reaction of investors to the announcement of profit or loss. ERC shows the strength of the weak market reaction to earnings announcements, so that it can be used to predict the content in earnings information. If investors have a perception that financial information has high credibility, then he will react strongly to these financial statements(Kusumawati \& Wardhani, 2018).

This research conforms to the research conducted by imroatussolihah (2013), that earnings persistence does not influence ERC since investors, in making investment, do not consider company's positive earnings persistence, but view and assess company from other factors which may influences its information. This research also conforms to the research conducted by Putri and Fitriasari (2017), that the reason earnings persistence does not influence earnings quality is that some companies in this research have their earnings declining in the year of observation but have high earnings persistence value. This causes bias in the research, thus earnings persistence value lack accuracy in describing earnings quality. Companies with high earnings persistence value tend to have low earnings quality (ERC). Ali and Zarowin in Marisya and Fitrisari (2017) state that the reason earnings persistence does not influence ERC is that the existence of transitory components. The high extent of transitory components in earnings results in too low ERC value, since earnings which contain high transitory value cannot be used in ERC measurement.Declining persistence of earnings also indicates the existence of a transitory component in profit which is a component that only affects a certain period, the occurrence is not persistent or not continuous, and results in a number of profit (loss) reported in the income statement fluctuating. The existence of a transitory component in profit causes earnings to be less permanent or profits have a persistent low(Nuraeni, Mulyati, \& Putri, 2018).

According to Afni (2014), a company sometimes has high earnings but they decline in the following year, showing that there is no earnings persistence, making the company less persistent. Generally, such earnings receive investors' low response for showing no earnings quality. This shows that investors do not only take earnings persistence as one indicator in their investment decision, but company's less informative earnings result in investors' less reactive to earnings publication. According to Kremer and Nautz (2012), herding behavior occurs when the market lacks transparency, which is when investors face uncertain source of public information and receive unclear signal of company's future. According to Bikhchandani and Sharma (2001), when an investor has limited information, he will follow other investors' move in making investment decision. He will eventually ignore his signal and follow majority investors' decision (herding behavior). Investor do, in making investment, not only view company's earnings, but also view other investors' behavior because of their limited information. With regard to ERC, investors do not always respond to earnings as something positive, but they conduct investment analysis based on certain momentum or their own psychology, thus earnings are not the only criteria investors refer to for investment.

\section{CONCLUSION}

This research concludes that Independent commissioner does not significantly influence earnings quality. This research conforms to the research conducted by Marisatussholekha and Budiono (2013), that investors' response to earnings quality is not determined by the number of existing independent commissioners in a company. Earnings persistence does not significantly influence earnings quality. This research conforms to the research conducted by imroatussolihah (2013), that earnings persistence does not influence ERC. Herding behavior does not significantly influence earnings quality. This research is expected to be useful for many parties, particularly those with interest in company that utilize financial 
information in their decision making. This research is expected to be used by financial statement users, particularly earnings information with regard to agency, investor's behavior and company management issues which will then influence earnings quality. This research's limitation is related to the number of samples, in which not all companies of manufacturing sector may be taken as its sample because of their limited information and negative abnormal return.

\section{REFERENCES}

Afni, S. M. 2014. Pengaruh Persistensi Laba, Alokasi Pajak Antar Periode, Ukuran Perusahaan, Pertumbuhan Laba Dan Profitabilitas Terhadap Kualitas Laba (Studi Empiris pada Perusahaan Manufaktur yang Terdaftar di BEI 2010-2012). JurnalDipublikasikan. Universitas Riau. Pekanbaru.

Andreas, H.H.(2012). Spesialisasi Industri Auditor Sebagai Prediktor Earnings Response Coefficient Perusahaan Publik Yang Terdaftar Di Bursa Efek Indonesia. Jurnal Akuntansi dan Keuangan. 14 (2).

Ardianti, R. (2018). Pengaruh AlokasiPajak Antar Periode , Persistensi Laba, Profitabilitas Dan Likuiditas terhadap Kualitas Laba (Studi Empiris Pada Perusahaan Manufaktur Yang Terdaftar Di Beitahun 2012-2016). Jurnal Akuntansi, 6(1), 88-105.

Asri, M. 2015. Keuangan Keperilakuan. Yogyakarta : BPFE Fakultas Ekonomika dan Bisnis UGM.Bikhchandani, S. dan Sharma, S. 2001. Herd Behaviour in Financial Markets : A Review. IMF Working Paper,

Budianto, R., \& Samrotun, Y. C. (2018). Pengaruh Good Corporate Governance (Gcg) Terhadap Kualitas Laba Pada Perusahaan Manufaktur Yang Terdaftar Di BEI 2015-2017. Prosiding Seminar Nasional : Manajemen Akuntansi, Dan Perbankan1, 411-424.

Christiantie, J., \& Christiawan, Y. J. (2013). Analisis pengaruh mekanisme corporate governance dan reputasi KAP terhadap aktivitas manajemen laba. Business Accounting Review, 1.

Fanani, Z. (2010). Analisis faktor-faktor penentu persistensi laba. Jurnal Akuntansi dan Keuangan Indonesia, 7(1).

Farida, D. N. (2012). Pengaruh dewan komisaris independen terhadap kualitas laba dengan konsentrasi kepemilikan sebagai variabel pemoderasi. Prestasi, 9(1).

Fauziah, S. (2017). Pengaruh Profitabilitas, Persistensi Laba, Struktur Modal, Dan Risiko Sistematik Terhadap Earnings Response Coefficient (Erc). Journal Of Accountng And Banking. 6 (1).

Febiani, S. (2012). Konservatisme akuntansi, corporate governance, dan kualitas laba (studi empiris pada perusahaan manufaktur di BEI). Jurnal Ilmiah Mahasiswa Akuntansi, 1(2).

Ghozali, I. (2005). Aplikasi analisis multivariate dengan program IBM SPSS 20 (edisi 6). Semarang: Badan Penerbit Universitas Diponegoro

Indrawati, N., \& Yulianti, L. (2010). Mekanisme corporate governance dan kualitas laba. Pekbis Jurnal, 2(2).

Imroatussolihah, Ely. 2013. Pengaruh Risiko, Leverage, Peluang Pertumbuhan, Persistensi Laba dan Kualitas Tanggungjawab Sosial Perusahaan terhadap EarningsResponse Coefficient pada Perusahaan High Profile. Jurnal Ilmiah Manajemen 1(1). 
Jonathan, J., \& Machdar, N. M. (2018). Pengaruh Kualitas Laba Terhadap Nilai Perusahaan Dengan Reaksi Pasar Sebagai Variabel Intervening. Jurnal Riset Manajemen dan Bisnis (JRMB) Fakultas Ekonomi UNIAT, 3(1), 67-76.

Khafid, Muhammad. (2012). Pengaruh tata kelola perusahaan dan struktur kepemilikan terhadap persistensi laba. Jurnal Dinamika Akuntansi. 4 (2)

Kremer, S. dan Nautz, D. (2012) Cause and consequences of Short-Term Institutional Herding. JEL Classification : G11, G24.

Kusumawati, H., \& Wardhani, S. L. (2018). Analisis Determinan Yang Mempengaruhi Kualitas Laba Studi Pada Perusahaan Manufaktur Di Bursa Efek Indonesia (Periode 2012-2016).

Mariatusholekha \& Boediono.E. (2015). Pengaruh Komisaris Independen, Reputasi Kap, Persistensi Laba, Dan Struktur Modal Terhadap Kualitas Laba (Studi Pada Perusahaan Telekomunikasi Yang Terdaftar Di Bursa Efek Indonesia Tahun 2009-2013). Jurnal Bina Ekonomi, 19 (1).

Marisya, G. Dan Fitriasari, P., (2017). Pengaruh Persistensi Laba, Good Corporate Governance dan Kualitas Audit Terhadap Kualitas Laba. Prosiding. Denpasar

Muema, S.M. (2014). The Herd Effect During An Initial Public Offering and Stock Returns At the Nairobi Stock Exchange. Research Project. School of Business University of Nairobi.

Mulyani, Asyik, Andayani., (2007). Faktor- faktor Yang Mempengaruhi Earnings Response Coeficient Pada Perusahaan Yang Terdaftar Di Bursa Efek Jakarta. Jurnal Akuntansi dan auditing Indonesia, $11(1)$.

Nasution, A. P., Nazar, M. R., \& Aminah, W. (2018). Pengaruh Leverage, Kualitas Audit Dan Dewan Komisaris Independen Terhadap Manajemen Laba (studi Pada Perusahaan Yang Termasuk Dalam Indeks Lq45 Tahun 2013-2016). eProceedings of Management, 5(3).

Nuraeni, R., Mulyati, S., \& Putri, T. E. (2018). Faktor-faktor yang mempengaruhi persistensi laba (studi kasus pada perusahaan property dan real estate yang terdaftar di bursa efek indonesia tahun 20132015). Accounting Research Journal of Sutaatmadja, 2(1), 82-112.

Nurochman, Afid, dan Solikhah. (2015). Pengaruh Good Corporate Tingkat Hutang Dan Ukuran Perusahaan Terhadap Persistensi Laba. Accounting Analysis Journal 4(4).

Rahmawati. 2005. Relevansi Nilai Earnings dengan Pendekatan Terintegrasi: Hubungan Nonlinier. Jurnal Akuntansi dan AuditingIndonesia 9(1).

Riyatno. (2007). Pengaruh keuangan dan bisnis. Jurnal Keuangan dan Bisnis, 5(2).

Rosdini, D. (2010). Pengaruh investment opportunity set dan corporate governance terhadap kualitas laba. Jurnal Akuntansi dan Keuangan, 5(2).

Rupilu, W. (2011). Pengaruh mekanisme corporate governance terhadap kualitas laba dan nilai perusahaan pada perusahaan manufaktur yang terdaftar di Bursa Efek Indonesia. Jurnal Akuntansi, Manajemen Bisnis, dan Sektor Publik, 8(1).

Suaryana, A. (2005). Pengaruh Komite Audit terhadap Kualita Laba. Jurnal Ilmiah Akuntansi dan Bisnis. $5(2)$

Susanto, Y. K. (2012). Determinan koefisien respon laba. Jurnal Akuntansi dan Manajemen, 23(3).

Surya, I., \& Yustiavandana, I. (2008). Penerapan good corporate governance Mengesampingkanhak-hak istimewa demi kelangsungan usaha. Jakarta: Kencana. 
I.Arisanti/Journal of Accounting and Business Education, 3 (2), March 2019 